\title{
Islam and the End of History
}

\author{
Ali A. Mazrui
}

\section{Introduction}

The debate about the end of history raises issues that sometimes touch almost upon the philosophy of history, insofar as they relate to the significance of not only a particular century but of the human species. Francis Fukuyama provoked this debate in his seminal article entitled, "The End of History?" in the journal The National Interest. ${ }^{1}$ At the end of the twentieth century, Fukuyama saw "an unabashed victory of economic and political liberalism. ${ }^{\prime 2}$ His central argument was that the whole world was moving towards a liberal democratic capitalist system that was destined to be the final sociopolitical paradigm of all human evolution. As Fukuyama put it:

What we may be witnessing is just not the end of the Cold War, or the passing of a particular period of postwar history, but the end of history as such: that is, the end point of mankind's ideological evolution and the universalization of Western liberal democracy as the final form of human government. ${ }^{3}$

For Fukuyama, at the time of writing the original article (in 1989), the momentous changes in Eastern Europe and the former Soviet Union,

Ali A. Mazrui is Director, Institute of Global Cultural Studies, and Albert Schweitzer Professor in the Humanities, State University of New York at Binghamton, New York; Albert Luthuli Professor-at-Large, University of Jos, Jos, Nigeria; and Senior Scholar and Andrew D. White Professor-at-Large Emeritus, Cornell University, Ithaca, New York. This is an expanded version of a lecture delivered at the University of Malaysia, Penang, Malaysia, and at Dewan Bahan dan Pustaka, Kuala Lumpur, Malaysia, in September 1992, under the sponsorship of Dewan Bahan dan Pustaka.

${ }^{1}$ Francis Fukuyama, who previously worked for the United States State Department and was, at the time of writing this article, working for the Rand Corporation, published "The End of History?" in The National Interest (Spring 1990). It was reprinted in Taking Sides, 3d ed., John T. Rourke, ed. (Guilford, CT: The Duskhin Publishing Group, 1991).

${ }^{2}$ Fukuyama, in Taking Sides, p. 340.

${ }^{3}$ Ibid., p. 341. 
which were only just unraveling, were part of that historical evolution towards democratic capitalism that he argued all societies would experience sooner or later. Fukuyama has since expanded his thoughts into a book. $^{4}$

\section{Fukuyama's Thesis and the Muslim World}

For our purposes, we may ask, how does this thesis relate to the Muslim world? Is our Muslim society also evolving towards a system of liberal capitalist democracy? Or will Islam provide an alternative concluding paradigm to human history? Muslims in fact believe not so much in the end of history as in the end of religious history.

Islam considers itself to be both the inheritor and the continuation of the Abrahamic tradition in history. It is stated in the Qur'an:

$\mathrm{He}$ has made plain to you of the religion that $\mathrm{He}$ enjoined upon Nūh and that which We have revealed unto you, and that which We enjoined upon Ibrāhīm and Mūsā and 'Îsā, that you keep to obedience and be not divided therein. $(42: 13)^{5}$

Muslims see the Prophet Muhammad as the last of the prophets. Muslims claim that both the Jews and the early Christians had prophesied the coming of Muhammad and the Qur'an. With regards to the Jews, the Qur'an asserts:

Say: Have you considered if it is from Allah, and you disbelieve in it, and a witness from among the children of Israel has borne witness of one like it, so he believed, while you are big with pride; surely Allah does not guide the unjust people. (46:10)

With respect to the Christians, Muslims believe that Jesus had already informed his followers about the coming of the last prophet. The Qur'an asserts:

And remember, Jesus, the son of Mary, said: O children of Israel! Surely I am the apostle of Allah to you, verifying that which is before me of the Tawrah and giving the good news of an Apostle

${ }^{4}$ See Francis Fukuyama, The End of History and the Last Man (New York and Toronto: Free Press \& Maxwell MacMillan Canada, 1992).

${ }^{5}$ All quotations in this paper are taken from The Qur'an, 6th ed., trans. M. H. Shakier, (Elmhurst, NY: Tahrike Tarsile Qur'an, Inc., 1990). 
who will come after me, his name being Abmad; but when he came to them with clear arguments they said: This is clear magic. $(61: 6)$

One may ask: to what extent has history vindicated these Muslim beliefs?

History has so far proven Muhammad to be the last of the grand founders of grand religions. Islam is the youngest of the grand global sacred faiths. And it is arguable that since Islam was born more than fourteen centuries ago, no religion has become numerous enough to be the national religion of even a single country in the twentieth century. Is Islam then the concluding chapter of religious history in the world? The Qur'an states explicitly that Muhammad is the last of the prophets: "Muhammad is not the father of any of your men, but he is the apostle of Allah and the last of the prophets" (Qur'an 33:40).

Does the expression "the last of the prophets" mean that he is in fact declaring the end of religious history since this is the final conclusion of this particular phase of human experience? Are Muslim societies therefore vindicated by fourteen centuries in which no other prophet has repeated the grand religious construction?

But with regard to the secular side of the end of history, are Muslim societies nevertheless moving towards liberal democratic capitalism? In the last years of the twentieth century, the world of Islam is larger in population-and growing faster-than the world of liberal democracy. As Weeks has pointed out in a demographic study of Islamic nations: "At current rates of growth, the 1988 estimated population of some 980 million Moslems could nearly double to 1.9 billion before the year 2020, accounting then for 23 percent of the world's total." ${ }^{\prime \prime}$

While Islamic countries have a crude birth rate of 42.1 per one thousand population, developed countries have a crude birth rate of 13.1; while Islamic countries have an average rate of natural increase of 2.8 percent, that of developed countries is only 0.3 percent; and the average total fertility rate of Islamic nations is 6 percent, while that of developed countries is only 1.3 percent. $^{7}$

On the other hand, the world of capitalism encompasses both liberal democracies and most Muslim societies. It is also worth remembering that

6John Weeks, "The Demography of Islamic Nations," Population Bulletin (1988) 43, 4: 5 . Some have argued that low birth rates in the western world, vis-à-vis high birth rates in the developing world (most of which is not democratic), could pose a danger to "western values." The Birth Dearth (New York, NY: Pharos Books, 1991).

${ }^{7}$ Weeks, "The Demography of Islamic Nations," p. 13. 
while the Arab world is indeed the vanguard of Islamic civilization, it is not necessarily the vanguard of Islamic democracy. On the gender question, for example, Pakistan and Bangladesh have taken the lead in empowering Muslim women to the highest political offices in the land. ${ }^{8}$

Let us not forget the Arabia of Muhammad's time and what in fact the Prophet himself felt about women and womens' rights. Who was Muhammad's first wife? What was the relationship between them? To what extent was he "liberated" in contemporary terms? Let us remind ourselves that Muhammad's first wife was not only "a working woman" but was also his employer. Muhammad happily worked for a woman, sought her advice, and she was the first person to whom he brought his doubts about the revelation he had in the cave. Contemporary Saudi Arabia, under the Wahhäbī tradition, is very different from Muhammad's vision.

Saudi Arabia, as the custodian of Makkah and Madīnah, does not even permit women to be licensed to drive a car. A storm of controversy broke out when some Saudi women attempted to protest this rule during the build-up of American and allied forces during the Gulf War. ${ }^{9}$

Southeast Asian Islam may take the lead in accommodating cultural pluralism in the modern world. Despite tensions and occasional clashes between the Chinese, Indians, and indigenous peoples in these states, or between Muslims, Buddhists, Hindus, and Christians, most people in Southeast Asia seem to be more interested in economic progress than cultural hegemony. As Wang puts it:

ASEAN [i.e., the Association of South East Asian Nations] has thus far been successful in projecting an image of growth, security and confidence. Its existence provides a comparative perspective on ethnic and other rights. Its experience with its members' social, cultural, and political issues has heightened its sensitivity as a group to wider common issues. ${ }^{10}$

${ }^{8}$ Benazir Bhutto became Prime Minister of Pakistan in December 1988 and, at the time of this speech, was the leader of the opposition. Begum Khaleda Zia became Prime Minister of Bangladesh in December 1991. The leader of the opposition is also a woman: Sheikh Hasina Wajed.

${ }^{9}$ For reports on the "car-driving" question in Saudi Arabia, see The New York Times of November 7, 1990, p. 18; November 8, 1990, p. 15; November 13, 1990, p. 14; November 15, 1990, p. 19; November 18, 1990, p. 16; and December 8, 1990, p. 16.

${ }^{10}$ See Gungwu Wang, "Ethnicity and Religion in Social Development," in The ASEAN Success Story, ed. Linda G. Martin (Honolulu: East-West Center, 1987), p. 43. For a detailed description of the economic performance of ASEAN countries, see Seiji Naya, "Economic Performance and Growth Factors of the ASEAN Countries," ibid., pp. 47-87. 
It is conceivable that Southeast Asia will follow South Asian Islam on the gender question, politicizing women faster than Middle Eastern Islam and sharing power with women sooner than Middle Eastern Islam has been doing. At least, in these countries, there is more of a tendency to accept the participation of women in various political activities than in Middle Eastern countries. ${ }^{11}$

On the whole, Arab Islam is by definition less multicultural than nonArab Islam. After all, the Arab world fuses the Arabic language with the Islamic religion in day-to-day life. At one level this is a rich religious experience. But at another level, this is a less rich cultural experience than that of Muslims who pray in Arabic and recite poetry in another language, like Muslims in Southeast Asia, whose varied cultural streams flow into the river of Southeast Asian Islam. Of course, this is just part of the "long historical tradition in Southeast Asia of accommodating - and by degrees integrating-Islamic belief with local customs." ${ }^{12}$ Muslims who are not Arabs are at the very least bicultural.

Islam in the twentieth century has posed the greatest cultural resistance to western imperialism but not necessarily to western liberal democracy. It has posed resistance to western secularism but not necessarily to western capitalism. Do these tensions amount to a distinct role that Islam plays in relation to precisely this idea of the liberal democratic system as the concluding chapter in human history?

A large number of recent Muslim theologians have asked for liberalization and reformation in Islam. We should not forget that Islam's communitarianism and political agenda are concomitant with the fact that rather than having a static theology, it contains many mechanisms for reform, innovation, and adaptation. Modem theological movements reflect this aspect of Islam. These include confrontation of Islam with western colonial might, modem eschatology, and basic challenges to the core of the religious law expressed in changes in family structure, dress codes, and anti-monotheistic literature and movements.

A sample of modern thinkers who were active in the nineteenth and twentieth centuries would include Jamāl al Dīn As‘adābādī (known as al Afghānī in the West), Muhammad 'Abduh, and Muhammad Iqbāl.

\footnotetext{
${ }^{11}$ For a critical look at women and politics in two Southeast Asian countriesMalaysia and Indonesia-see Lenore Manderson, "Gender and Politics in Malaysia," in Why Gender Matters in Southeast Asian Politics, ed. Maila Stivens (Clayton, Australia: Centre of Southeast Asian Studies, 1991), pp. 43-60; and Norma Sullivan, "Gender and Politics in Indonesia," ibid., pp. 61-86.

${ }^{12}$ Roy F. Ellen, "Social Theory, Ethnography and the Understanding of Practical Islam in South-East Asia," in Islam in South-East Asia, ed. M. B. Hooker (Leiden, The Netherlands: E. J. Brill, 1983), pp. 50-91.
} 
These theorists were Muslims with European education who also had an intimate knowledge of the western world's science and technology, as well as its social problems. Their attitudes outline a political-theological challenge to the West on the basis of Islamic rationalism. ${ }^{13}$

As'adābādī's theology is intertwined with his political response to the forceful power of European Christian civilization. He recommends, on theological grounds, a pan-Islamic movement that can revive the caliphate and establish Islamic force as a world power. As a political realist, this grand vision is transferred to a call for an Islamic nationalism that stands free of western economic domination. To support this plan, he appeals for: first, immediate political and economic independence; second, a recognition that the ultimate superiority of Islam over other religions, as the $\mathrm{Mu}$ 'tazilah assert, lies in its rationality; and third, the idea that the practical result of a religious life includes not only humanity's spiritual dimension and the special status of religious community, but also special inner qualities necessary for achieving peaceful bliss (i.e., modesty, honesty, and truthfulness that frees humanity from the consequences of hedonism and materialism).

As'adābādī, like many modern reformers, was a major organizer of a group of reform movements such as Egypt's Salafiyah and the Muslim Brotherhood. One of his proteges was Muhammad 'Abduh, a philosopher, a professor at al Azhar University, a journalist, and a mufti (chief judge) who proposed large-scale social programs for long-term social reform. He taught theology and wrote a number of works, including legal opinions, that, for example, permitted the eating of animals slaughtered by Jews and Christians, legalized loans on interest, and advocated reforms of women's rights. His theology focused on a close connection between reason and revelation. The latter, according to him, was intuitive knowledge given by God to the Prophet for the education of the common man or woman and not necessarily to be reserved for exegesis by a few. Like the Mu'tazilah, 'Abduh felt that the Qur'an was created in time and that theology is a rational science. Also, like As'adābādī, he invited Muslims to hold fast to the fundamentals of their religion while focusing on reform and the innovation of practices open to reasoned reinterpretation and modernization.

Muhammad Iqbāl (1878-1938) considered Islam as an intellectual and moral phenomenon that places humanity, as an innovative instrument of

${ }^{13}$ See Muhammad Abduh, The Theology of Unity, trans. Kenneth Cragg and Ishaq Muhammad (New York: Humanities Press, 1966); Muhammad Iqbal, The Reconstruction of Religious Thoughts in Islam (Lahore, Pakistan: Sh. Muhammad Ashraf, 1951); and Islam in Transition: Muslim Perspectives, ed. John Donohue and John L. Esposito (New York: Oxford University Press, 1982). 
God, in a position to realize the infinite possibilities of the world. Iqbāl held that the Islamic intellectual tradition transforms Greek models of abstract knowledge into empirical investigation of concrete facts, as illustrated by the Qur'an's attention to actual matters. Faith involved empirical knowledge of reality coupled with the vision of theory. Thus, the knowledge of how God reveals Himself in the world is compatible with the idea of a transcendent God. Islam has always had a keen sense of historical consciousness, and thus Muslims have traditionally considered themselves to be participants in the making of history.

\section{Western and Islamic History}

In western history, intellectual and scientific changes paralleled religious and economic changes. The changes exemplified by the former were: the Renaissance, which created individualism in the arts and blossomed into a major movement in Europe; the Enlightenment, which produced European-style rationalism with its cultivated skepticism and doubts; and the Scientific-Technological Revolution, during which the first great scientists emerged, the beginnings of sustained secularism formed, and the scientific revolution gathered momentum. As one scholar said:

The vivid imagination of the Renaissance mind had revived the logic and induction and a biblical appreciation of humankind as observer and manipulator of creation while Reformed thought renewed hope in history and tamed nature for investigation. This was the combination that made modern science possible. ${ }^{14}$

Paralleling these developments, the sixteenth-century Protestant Reformation in the religious domain began. It was inevitable, with the opening of the mind and the world through the Renaissance and the Age of Discovery, that there would be a questioning of Church authority and dogma. $^{15}$

The economy was not immune to these changes in society. There were higher phases of economic behavior that started before the Protestant Reformation but afterwards entered more developed phases, resulting

\footnotetext{
${ }^{14}$ Harold P. Nebelsick, The Renaissance, The Reformation and the Rise of Science (Edinburgh, Scotland: T \& T Clark, 1992), pp. xix.

${ }^{15}$ For historical accounts of the links between the Renaissance and the Reformation, see, for example, William R. Estep, Renaissance and Reformation (Grand Rapids, MI: William B. Eerdmans, 1986); and Albert Hyma, Renaissance To Reformation (Grand Rapids, MI: William B. Eerdmans, 1951).
} 
in a capitalist revolution. In examining this period, one issue has been much debated: did the change in the religious domains result in major changes in economic behavior? A major sociological writer in the West, who initiated the debate on the link between the Protestant Reformation and the rise of capitalism, was Max Weber, author of the famous book The Protestant Ethic and the Spirit of Capitalism. ${ }^{16}$ The argument was that Christianity, before the Protestant Reformation, distrusted making money, particularly through loans and interest. ${ }^{17}$ Making money was not morally respectable because of the strong biblical injunctions against riches and usury. For example in Mark 10:25, Jesus said, "It is easier for a camel to pass through the eye of a needle than for a rich man to enter the kingdom of heaven." ${ }^{18}$ Poverty was prized by faithful Christians.

Therefore, the tendency was to let Jews monopolize money making. Since Jews were despised because of their perceived role in Jesus Christ's crucifixion, anti-Semitic Europe assigned the necessary evil of moneylending and other banking functions to them. ${ }^{19}$ So the specializations that were taking place in Europe were due to pre-Reformation Christianity's distrust of certain forms of economic behavior that it regarded as religiously and morally less than respectable.

Then came the Protestant Reformation. It was pioneering in certain ways. First of all, it distrusted the Church and its authorities. This was a blow not against Christianity, but against the Church. And at that time the dominant church was the Roman Catholic Church. Second, it distrusted priestly intercession-the representation of God by priests. People went to confess to a priest in order to be forgiven by God, or they went to buy indulgences. One paid some money to the Church so that the Church could allow one to drink more wine. So the Church had reached a stage where it was doing all sorts of things on behalf of God, sometimes in ex-

${ }^{16}$ Max Weber, The Protestant Ethic and the Spirit of Capitalism (New York: Charles Scribner's Sons, 1958); M. J. Ketch, Capitalism and the Reformation (New York: Barnes \& Noble, 1968); Jelle C. Riemersma, Religious Factors in Early Dutch Capitalism 15501650 (The Hague, Paris: Mouton, 1968); Wolfang Schluchter, Rationalism, Religion and Domination: A Weberian Perspective (Berkeley: University of Berkeley Press, 1989); and, for an early overview of the controversy, see Robert W. Green, Protestantism, Capitalism and Social Science: The Weber Thesis Controversy, 2d ed. (Lexington, MA: Heath, 1973).

${ }^{17}$ Canon law threatened expulsion from the Church for those who continued to engage in usury despite the Church's warning. See Hyma, Renaissance to Reformation, p. 66.

${ }^{18}$ The Holy Bible. ed. Rev. C. I. Scofield (New York: Oxford University Press, 1909). Oft-cited verses against usury include Psalms 15:5 and Ezekiel 18:8, 13, and 17.

${ }^{19} \mathrm{See}$, for example, H. A. Oberman, The Roots of Anti-Semitism in the Age of Renaissance and Reformation (Philadelphia: Fortress Press, 1984); and William Nicholls, Christian Antisemitism: A History of Hate (Northvale, NJ: J. Aronson, 1993). 
change for bribes! Outraged by this, Martin Luther and John Calvin became the major movers of change, with Martin Luther hammering and nailing his ninety-five theses on a church door in Wittenburg in 1517, denouncing the abuses of Christianity, and starting a movement that soon spread across northern Europe and subsequently penetrated much of the rest of the world through Protestant proselytization. Thus priestly intercession began to be challenged in the Protestant Reformation. An outraged Martin Luther, for example, said:

Popes and bishops are flinging about graces and indulgences. Here come religious men and flaunt their indulgence at every street comer, only to get money for food and clothes. Oh, those begging friars! ${ }^{20}$

Third, this marked the beginning of individualism in the new western culture. It was felt that one could talk to God directly and that the Almighty could talk to you directly, and that there was therefore no need for priestly intermediaries. Since one did not need a priest to talk to God, there was religious individualism. And then from religious individualism, there was a transition to economic individualism.

Fourth, there are different forms of prayer. Work itself was considered a form of prayer. Work and prosperity can be signs that God is on your side. ${ }^{21}$ Prosperity is not disteputable, for it can be a sign that God approves of one's actions. So it is not the making of money that is sinful, but how you spend it. And the Protestant Reformation veered towards a situation here that proclaimed, "Make money but don't spend it. Make lots of money, but spend very little." The result: accumulation on one side, reinvestment on the other, and the beginnings of a massive accumulation of wealth, because people who previously would not have entered the market place were now entering and interpreting it as a form of prayer. People who were God-fearing were at the same time eager to become rich and yet they were not spending their wealth in luxury. They were saving it, sometimes for reinvestment. Capitalism was about to take off. And capitalism took off.

The marriage of these two-the scientific revolution and the capitalist revolution-gave the West the Industrial Revolution. From the late eighteenth century to the early part of the nineteenth century, the revolution burst upon the hitherto-placid world, with England leading the way for

${ }^{20}$ Quoted in Hyma, Renaissance to Reformation, p. 273.

${ }^{21}$ Ibid., pp. 490-91. 
much of the period. Most spheres of life were transformed by the revolution.

And the argument was: look who is leading in the Industrial Revolution and the capitalist changes-the Protestant powers. On the other hand, the ones who were stagnating were the most Catholic of the Christian countries, for Portugal, Spain, and Ireland were falling behind the Protestant powers that were developing in a big way. There was one big exception among Catholic countries, one that became a major actor in the game of capitalism and industry without being Protestant: France. ${ }^{22}$

However, although France did not have a Protestant Reformation, it had a functional alternative: the French Revolution. ${ }^{23}$ In some ways, the Revolution was at least as anticlerical as the Reformation and proceeded to change the nature of economic, as well as religious, behavior in France. ${ }^{24}$ The Industrial Revolution and the capitalist revolution were responsible for the later revolutions; on the one side, there were liberal revolutions and on the other side were the later socialist revolutions. The most influential of the liberal revolutions were the ones in the United States (from 1776 onwards) and France (from 1789)-the American and French revolutions. The most spectacular of the socialist revolutions were of course the ones in Russia (1917) and China (1949). This view of western history is not Fukuyama's: it is Mazrui's.

What Fukuyama was telling us is that socialist revolutions were doomed; this was the march of history. Ideologies attempted to achieve utopia for their followers, and socialism, which had exerted a powerful hold on the minds of millions for decades, was the last utopia. The last utopia is now crumbling. In the words of Fukuyama:

${ }^{22}$ For a comparative look at France's and Britain's industrial-technological progress, see, for example, J. R. Harris, Essays in Industry and Technology in the Eighteenth Century: England and France (Hampshire, UK, and Brookfield, VT: Variorum and Ashgate, 1992).

${ }^{23}$ For instance, see Jean-Pierre Hirsch "Revolutionary France, Cradle of Free Enterprise," American Historical Review (December 1989), 94: 5: 1281-89.

${ }^{24}$ For analyses of the economic nature and impact of the French Revolution, see, for example, Florin Aftalion, The French Revolution: An Economic Interpretation (Cambridge, UK, and New York: Cambridge University Press, 1990); Jean Laurent Rosenthal, "The Development of Agriculture in Provence 1700-1860: The French Revolution and Economic Growth," Journal of Economic History (September 1990), 50: 3: 615-38; and Peter McPhee, "The French Revolution, Peasants, and Capitalism," American Historical Review (December 1989), 94: 5: 1265-80. For origins and consequences in other areas of society, see, for example, Roger Chartier, The Cultural Origins of the French Revolution (Durham, NC: Duke University Press, 1991); Alan Forrest and Peter Jones, eds., Reshaping France: Town, Country, and Region during the French Revolution (Manchester, UK, and New York: Manchester University Press and St. Martin's Press, 1991); and David G. Troyansky et al., The French Revolution in Culture and Society (New York: Greenwood Press, 1991). 
The passing of Marxism-Leninism first from China and then from the Soviet Union will mean its death as a living ideology of world historical significance ... the fact that there is not a single large state in which it is a going concem undermines completely its pretensions to being in the vanguard of human history. ${ }^{25}$

\section{Is Marxism Dead?}

Now, in our own lifetime, with the collapse of the socialist revolution, at least in Europe, I have raised the issue of whether the fate of Marxism remains open. ${ }^{26}$ What has collapsed seems to be Lenin's contribution. Lenin was a Russian, primarily a twentieth-century figure, and Marx an exclusively nineteenth-century German thinker. Lenin was a kind of Martin Luther, interpreting the Marxist gospel. ${ }^{27}$ Just as there are different routes to Christianity-one does not have to be Lutheran to be Christian - there are different routes to Marxism, for one does not have to be Leninist to be Marxist. The strange package of the twentieth century is that Leninism was Marxism's false start. As Russia was the first to take off and Lenin was the Russian leader, almost everybody else who went Marxist went Marxist-Leninist. This combination of Marxism-Leninism was seen as indissoluble. The Leninist part of the package included, for instance, democratic centralism, the vanguard party, and the monopolistic communist party. ${ }^{28}$ These concepts owed more to Lenin than to Marx.

There were three roles of Marxism in our history: a) as an ethic of distribution (how to distribute the wealth of society and therefore reduce the inequalities of society); b) as a methodology of analysis (a Marxist way of studying society, of interpreting society, of looking at society and drawing conclusions); and c) as an ideology of development, as an engine to increase productivity.

An evaluation of the first role of Marxism - as an ethic of distribution and concern about economic disparities or inequalities-reveals that it really has not been invalidated by the crisis that has taken place. The idea that we ought to minimize differences in the sharing of resources in so-

${ }^{25}$ Fukuyama, in Taking Sides, p. 355.

${ }^{26}$ See A. A. Mazrui, "The Resurgence of Islam and the Decline of Communism: What Is the Connection?" Futures (United Kingdom: Buttersworth, 1991), pp. 273-88.

${ }^{27}$ See, for example, Paul LeBlanc, Lenin and the Revolutionary Party (Atlantic Highlands, NJ: Humanities Press International, 1990).

${ }^{28}$ See, for example, The Fundamentals of Marxist-Leninist Philosophy, trans. Robert Daglish (Moscow: Progress Publishers, 1974). 
ciety has not been invalidated one way or the other. ${ }^{29}$ To treat the second role-Marxism as a methodology of analysis-we may point out that though you and I may not be Marxist scholars, the history of the last three years has not invalidated class analysis or the study of imperialism. We may prefer to study societies differently, which is the privilege of each scholar, but Marxist methodology has not been rendered unintelligible or unintelligent. ${ }^{30}$ Lastly, Marxism as an ideology of development has been discredited. It has not delivered the goods because Lenin constructed a particular form or strategy for development that failed to deliver in the countries in which it was attempted. ${ }^{31}$ And so it has more or less collapsed in many countries. The Marxist baby is being thrown out with the Leninist bath water.

It is conceivable that Marxism stands a better chance in Asia, at least in the People's Republic of China, where it has not as yet been abandoned. China, despite Tiananmen, is becoming less Leninist, particularly in the economic sphere. Democratic centralism is losing its centralism, and we may surely see an increase in the "democratic" part of "democratic centralism. ${ }^{\prime 32}$

If it happens that Marxism survives better in Asia than in Europe, the situation would be comparable to the fate of Christianity, a religion that failed among its original constituency. It failed among the Jews to whom it was first revealed and it failed in the Middle East as a geographical region. It prospered spectacularly in Europe-in exile. Europe then became the leading Christian continent in the world and spread Christianity to

\footnotetext{
${ }^{29}$ Even formerly hard-headed economists are now turning their eyes towards the "fuzzy" topics of "equality." One example is Amartya Sen. See, for example, his Inequality Reexamined (Cambridge, MA: Harvard University Press, 1992). Equality continues to occupy the minds of political theorists. See, for instance, David G. Gil, Unraveling Social Policy: Theory, Analysis, and Political Action toward Social Equality, 4th ed. (Rochester, VT: Schenkman Books, 1990); and Charles R. Beitz, Political Equality: An Essay in Democratic Theory (Princeton: Princeton University Press, 1989).
}

${ }^{30} \mathrm{~A}$ recent library search yielded some 1,510 books and 1,356 articles on the political economy subfield, which borrows heavily from Marxian analysis.

\footnotetext{
${ }^{31}$ For a recent overview of the political and economic transformations in Eastern Europe, see Ferenc Fehér and Andrew Arato, eds., Crisis and Reform in Eastern Europe (New Brunswick, NJ: Transaction Books, 1991).

${ }^{32}$ Recent reports in newspapers and the release of political prisoners seem to indicate an easing of the tight political controls. See, for example, The New York Times, June 1, 1993: A1. China's economy is definitely booming at a tremendous rate, although problems remain. See, for example, C. A. Tisdell, Economic Development in the Context of China: Policy Issues and Analysis (New York: St. Martin's Press, 1993).
} 
other lands. ${ }^{33}$ Even under European hegemony, it still did not prosper where it was born. And even when Europeans created Israel, it was partly at the expense not only of Muslims but also of Christians, for Europeans brought in Jews while Christian and Muslim Palestinians fled the area. An estimated fifty thousand Christian refugees fled the part of Palestine that fell to the Zionists during the first Arab-Israeli war of $1948-49 .{ }^{34}$ So the creation of Israel reduced the Christian presence in the Middle East even further because it displaced one particular subsection of the region's residual Christian population. There was a steep decline in the number of Palestinian Christians in various areas of Palestine between 1931 and 1961. In New Jerusalem, the number of Christians fell from 11,526 in 1931 to 1,403 in 1961 . $^{35}$

The question is: Is Marxism moving in a similar direction? Will it prosper in exile and become marginal in Europe where it was born? In its cradle-Europe-it may become peripheral, while in the largest and most populous of all continents-Asia-it may find pockets of strength. At the moment, the biggest pocket of all is China. It is a question mark. Is it the end of history, or the end of Leninism, that is at hand? It is a question that only history will answer more fully in the future.

\section{Islam in World History}

Is there an Islamic equivalent to this kind of history described above? What form does it take? Let us raise at the outset the most controversial aspect. Is it possible to argue that the Prophet Muhammad saw (some seven centuries or so before Martin Luther and John Calvin) that the Christianity of his day needed a reformation?

The Qur'an asserts that the people of the book (i.e., the Jews and the Christians) have altered their original text:

O you who believe! Believe in Allah and His Apostle and the Book which $\mathrm{He}$ has revealed to His Apostle and the Book which He revealed before; and whoever disbelieves in Allah and His Angels and His Apostles and the last day, he indeed strays off into a remote error. $(4: 136)$

${ }^{33}$ For a noncritical account of the western role in expanding Christianity to the nonwestern world, see Charles W. Forman, ed., Christianity in the Non-Western World (Englewood Cliffs, NJ: Prentice-Hall, 1967), pp. 35-58. 67.

${ }^{34}$ See R. B. Betts, Christians in the Arab East (Atlanta: John Knox Press, 1978), p.

${ }^{35}$ Ibid., p. 69. 
This is true, even though the Christians are nearest in friendship to Muslims. As the Qur'an puts it:

And you will certainly find the nearest in friendship to those who believe (to be) those who say: We are Christians; this is because there are priests and monks among them and because they do not behave proudly. (5:82)

One of the major mistakes of Christians was their conviction that because Jesus was born of a virgin, he was therefore a son of God:

And The Jews say: Uzair is the son of Allah; and the Christians say: The Messiah is the Son of Allah; these are the words of their mouths; they imitate the saying of those who disbelieved before; may Allah destroy them; how they are turned away. (9:30)

Thus Muhammad asserts that the Christians had distorted the real message of God. Seven centuries later, and in the same manner, John Calvin and Martin Luther said that the message of Jesus had been distorted by some of its followers. For the Muslims, God is absolute and does not have a family. Specifically the celebrated Chapter of Purity asserts: "Say: He, Allah is One. Allah is $\mathrm{He}$ on Whom all depend. $\mathrm{He}$ begets not, nor is He begotten. And none is like Him" (114:1-4).

John Calvin and Martin Luther would not have accepted that, but they did restrict the sharing of divinity. They agreed that Mary, the mother of Jesus, was special but not so special that one could pray to God through her. Protestants place less emphasis on her significance than do Roman Catholics. For instance, Martin Luther wamed against giving her divine status or venerating her more than Jesus Christ. ${ }^{36}$ Similarly, Martin Luther and John Calvin said that one does not have to pray to God through priests; one can have direct communication with Him. They were saying in the sixteenth century what had been said by Muhammad in the seventh. Here is a situation where Islam said the body of Christianity, or what others call Christianity, is properly the religion of God and that the priests have taken over as pretenders to godly authority.

Was Islam the first Protestant revolution? That is the question. It had accepted the message of what others call Christianity, asserted it had been distorted, and proceeded to attempt to purify it without necessarily undermining Jesus as a major figure in spiritual worth. And then, is there an

${ }^{36}$ Bernhard Lohse, A Short History of Christian Doctrine, trans. F. Ernest Stoeffler (Philadelphia: Fortress Press, 1978), p. 207. 
effect that leads to a form of mercantilism in trade after Muslims expanded? This is really a nascent capitalist revolution trying to take form. That is one stage.

Is there a similar stage of an Islamic renaissance in the arts and sciences? If this is what we mean by the major changes that took place in periods of Islamic history, an approximate extension of the then nascent scientific revolution depends on one's perspective. If one is too Arabocentric in the interpretation of the Islamic enlightenment, one will reduce the period of Islamic enlightenment to a brief period. If one extends the period well into the Ottoman empire, one can carry the period right into the seventeenth century. The Islamic enlightenment borrowed from other civilizations and then improved upon what it had borrowed. We know that in the English language the numbers are called Arabic numerals; this is part of the Islamic response to the stimulus of other civilizations. It passed on that stimulus, after improving it for future centuries and civilizations. In this case the stimulus was from India, and the Muslims transmitted it to other civilizations after improving upon it. ${ }^{37}$

The wisdom of the Greeks was originally transmitted to western Europe through such scholars as the Muslim Iranian philosopher Ibn Sīnā (a.k.a. Avicenna) and the Muslim Spanish thinker Ibn Rushd. ${ }^{38}$ Ibn Sinā's philosophical system was embedded in Christian Catholicism in many ways. For example, St. Thomas Aquinas, perhaps the greatest scholarly theologian, quotes his work over five hundred times and formulates his own key doctrines, such as the difference between "essence" and "existence," based on Ibn Sīnā's analysis. In the same manner, Ibn Rushd's commentaries on Aristotle were philosophical handbooks for some of the greatest Christian thinkers: Albert the Great and his celebrated student St. Aquinas. These commentaries have been translated into Latin and English and are still useful in deciphering Aristotle's works. ${ }^{39}$

Greek wisdom later became part of the West's self-conception and the origins and cradle of its own rationalism. ${ }^{40}$ The English word "alpha-

${ }^{37}$ See Duncan Towson, Muslim Spain (Cambridge, UK: Cambridge University Press, 1973), p. 41.

${ }^{38}$ See ibid, p. 42. Also see Hichem Djait, Europe and Islam (Berkeley, CA: University of California Press, 1985); and W. Montgomery Watt, The Influence of Islam on Medieval Europe (Edinburgh: University Press, 1972).

${ }^{39}$ See De Lacy O'Leary, Arabic Thought and Its Place in History (London: Routledge \& Kegan Paul, 1922); and Majid Fakhry, A History of Muslim Philosophy (New York: Columbia University Press, 1970).

\footnotetext{
${ }^{40}$ See, for example, G. E. von Grunebaum, Islam and Medieval Hellenism: Social and Cultural Perspectives (London: Variorum Reprints, 1976).
} 
bet" may not have come directly from the Greek "alphabita" but from the Arabic "alif bete." Although western European languages show otherthan-Arabic influences, Spanish has been particularly affected by Arabic partly because of the Muslim impact on Spain for about eight centuries. ${ }^{41}$

The architectural wonders of Muslim civilization extend from the Alhambra in Spain to the Taj Mahal in India. As I indicated, nor must we forget, the West's own Renaissance may be due to the Islamic renaissance in the first place. Here I quote one western scholar, Eugene A. Myers: "From the late ninth century until the twelfth, Islamic influence on Western science and culture was very great. ${ }^{142}$

And again, in conclusion, he states:

The cultural importance of the work of Islamic scholars and translators for the development of science and humanities can hardly be overestimated . . . thus, the roots of Western thought are a mixture of Greco-Arabic and Hebrew thought. ${ }^{43}$

It is a paradoxical development that the doors of Hellenism, which later inspired the western European renaissance, came largely through the Islamic world and particularly through Spain. So on the whole, therefore, all this has some equivalent in Muslim history, but in a nascent stage.

What happened afterwards? The figure begins to change as decline sets in. The West's Dark Ages came before the Renaissance, while ours came after the Renaissance. And then Muslims became objects of history. Not subjects of history, not actors, but the acted-upon. Depending on one's degree of Arabocentrism, one can choose the period-past the Moghuls, past the Ottoman Empire-as to when the decline really became sufficiently decisive.

I would say the first half of this century was still part of the decline. This was part of the period of Muslims as objects of history. Much of the Muslim world was colonized. The Ottoman Empire disintegrated after the First World War, and different pieces were occupied by European powers and became colonies or protectorates. ${ }^{44}$ Those parts of the Muslim world

${ }^{41}$ See Duncan Towson, Muslim Spain, for a general description of the impact of Islam on Spain.

${ }^{42}$ See Eugene A. Myers, Arabic Thought and the Western World in the Golden Age of Islam (New York: Frederick Ungar, 1964), p. 10.

${ }^{43}$ See ibid., pp. 133-4.

${ }^{44}$ For an overview of colonial empires, see David K. Fieldhouse, The Colonial Empires: A Comparative Survey from the Eighteenth Century, 2d ed. (London: Macmillan, 1982). 
that were not colonized were neo-colonized. Countries like Iran (or Persia) and Afghanistan did not have much independence in this period.

In the second half of the twentieth century, Muslims emerged as shapers of history. In this phase, Muslims affected world history, not by design but by attempting to change more localized history and then generating consequences abroad. So the unintended consequences became globally transformative. One major example was the war of independence in Algeria during 1954-62. ${ }^{45}$

One might think of the war in Algeria in Eurocentric terms. France regarded it as part of France, but the Algerians said "No way. This is a colony," and began to fight for their independence. Then a good Frenchman named General Charles DeGaulle came to power, recognized reality, and gave independence to Algeria in 1962. That is the wrong way of interpreting Algerian history. The correct way is to say Algerians are North Africans who took up arms to fight for their freedom. Their sole aim was to fight for their liberty and human rights. ${ }^{46}$ They did not know they were changing the history of the world.

How did they change the history of the world in four years (1954-58) only? They imposed so much stress on France's constitutional order, more stress in fact than the Vietnam war later imposed on its American counterpart, that France almost had a civil war. ${ }^{47}$ At that time, I was a student in England and I remember very distinctly, as we were watching the tensions across the Channel, wondering what was going to happen. The Manchester Guardian, for the first time in its history, carried an editorial in French appealing to the people of France to desist from this reckless plunge towards armed civil convulsion. If the frustrated and demoralized French soldiers in Algeria had flown to Paris to take over government, the left in France would have poured into the streets with arms to fight them. ${ }^{48}$

\footnotetext{
${ }^{45}$ For an account of the war, see, for example, John E. Talbott, The War without a Name: France in Algeria, 1954-1962 (New York: Knopf, 1980).

${ }^{46}$ The French attached immense importance to Algeria. See, for instance, Tony Smith, The French Stake in Algeria, 1945-1962 (Ithaca, NY: Cornell University Press, 1978).

${ }^{47}$ See W. G. Andrew, French Politics and Algeria: The Process of Policy Formation, 1954-1962 (New York: Appleton-Century-Crofts, 1962) for an account of French policy towards Algeria. For a more journalistic account of DeGaulle and Algeria, see C. L. Sulzberger, The Test: DeGaulle and Algeria (London: R. Hart-Davis, 1962).

${ }^{48}$ One of the most pressing problems in decolonizing Algeria was the large number of French ex-military personnel who had settled in Algeria. They were understandably enraged over any moves towards decolonization. There was also considerable sympathy within the French military for their view, leading to fears of a military coup in France itself. See, for example, G. A. Kelly, Lost Soldiers: The French Army and Empire in Crisis, 1947-1962 (Cambridge, MA: MIT Press, 1965).
} 
It was a close call. There was only one person who could save France: General Charles DeGaulle. The old constitutional order collapsed because DeGaulle would not rule under it. He insisted on the Fifth $\mathrm{Re}$ public - a whole new constitution had to be written. ${ }^{49}$ When it came into force, it made France more politically stable and enabled it to pull out of the military side of NATO. It made France less submissive to the United States for quite a while and also pushed its nuclear program faster. It accelerated France's decolonization policy throughout the world, especially throughout Africa. ${ }^{50}$ And by 1962 , Algeria itself became independent.

The history of France was changed because Muslims were fighting for their independence in Algeria, in North Africa. The history of Europe was changed because the history of France was changed. The history of the world was changed because the history of Europe was changed. So this is a situation of shapers of history shaping history while trying to change local history.

In relation to Fukuyama's thesis of the "end of history" as the collapse of communism, almost no western analysts talk about Afghanistan. Nobody discusses the end of communism in relation to the collapse of the Soviet imperial will when defeated in Afghanistan. Almost nobody does it in the West. Here was a country, the Soviet Union, that was hegemonic and powerful. Any time it had trouble in its empire it sent the tanks in response and crushed the trouble. It did this in Hungary in 1956 and in Czechoslovakia in 1968. It could not do it in Afghanistan from 1979 onwards because, unlike the architects of the Prague Spring in Czechoslovakia and unlike the Hungarians in 1956, the Mujahidin would not let the invaders lie in peace. They fought and fought and fought. They are still fighting, even though the invaders have left. Of course, sooner or later we have to remind them the invader is gone. But at least in the heroic phase of the struggle, they took on the superpower, aided by the fervor of Islam, just as earlier Islam had proved to be a potent force in fighting the imperialist powers, ${ }^{51}$ and the Soviet imperial will was damaged fatally. Nobody discusses this in the West: after Afghanistan, the Soviet Union could no longer send tanks into another Hungary, into another Poland,

\footnotetext{
${ }^{49}$ See, for example, P. M. Williams and Martin Harrison, DeGaulle's Republic (London: Longman, 1960).

${ }^{50}$ The impetus towards French peace movements and decolonization, as a result of the Algerian struggle, is well documented by David L. Schalk in his War and the Ivory Tower: Algeria and Vietnam (New York: Oxford University Press, 1991).
}

${ }^{51}$ See, for instance, Rudolph Peters, Islam and Colonialism: The Doctrine of Jihad in Modern History (The Hague: Mouton, 1979); and Oliver Roy, Islam and Resistance in Afghanistan, 2d ed. (Cambridge, UK, and New York: Cambridge University Press, 1990). 
into another Czechoslovakia. After being defeated by Muslims, it could no longer play that old game.

Nobody regards this as relevant, because they do not see the Muslim world as a causal factor in history. They still think of us as objects of history, objects being manipulated by historical forces. And yet Afghanistan is a tremendous case of a movement of Muslims pursuing local goals and, in the process, transforming global history. Many of the Mujahidin knew very little about perestroika and East-West relations. They just knew: we are Muslims, we love our freedom, we love our religion, and these invaders are not going to sleep in peace in my land; we are going to throw them out. So that was Muslims creating change by destroying the old Eastern bloc. Afghanistan's role was reinforced by Iran's role in creating conditions in which the Soviet Union intervened in Afghanistan in the first place, since it was scared of another Islamic revolution. ${ }^{52}$ All these are causal factors, with major Muslim actors, that were inadequately attended to in the explanation of shapers of modern history at work.

In South-South and North-South relations, Muslims have played a major role in challenging western control over Muslim resources. We also know about the role played by Nasser in challenging western control over Muslim resources. There is a Muslim impact on South-South relationsaid to each other and employment, as in the case of oil-rich Muslim countries. ${ }^{53}$ There is a Muslim impact on North-South relations, as in the case of negotiations with the North on key international and economic issues. ${ }^{54}$ Muslims have strengthened the South's power to some extent, and have succeeded in destroying the East's power. What is not clear is how we are going to deal with the West, as it is unfortunately still too strong for the Muslims. Is there a way out?

Thus we come to Muslims as makers of history. In my opinion, Muslims shape global history, but only unintentionally and with unintended consequences. Makers of history, on the other hand, do it intentionally and for that exact purpose. I think it is important that we confront

\footnotetext{
${ }^{52}$ See, for example, Lawrence Ziring, Iran, Turkey, and Afghanistan: A Political Chronology (New York: Praeger, 1981); and Yaacov Ro'i, ed., The USSR and the Third World: Issues in Domestic and Foreign Policy (London and Boston: Allen \& Unwin, 1984).
}

${ }^{53}$ See Shireen T. Hunter, OPEC and the Third World: Politics of Aid (Bloomington: Indiana University Press, 1984); and Abdelkader Benamara and Sam Ifeagwu, eds., OPEC Aid and the Challenge of Development (London and New York: Croom Helm, 1987).

${ }^{54}$ See James Piscatori, International Relations of the Asian Muslim States (Lanham, MD and New York: University Press of America and the Asia Society, 1986); and D. Abdullah, The Biting Falsehood: A Study of Islam and Western Thought (London: Ta-Ha Publishers Ltd., 1984). 
the issue of Fukuyama's democracy and capitalism and where it is leading Muslims. On the whole, I am much more enthusiastic about democracy than about capitalism. Unfortunately, capitalism may be the necessary manure for democracy. Historically, there has been no pluralistic democracy in the world that has succeeded without a minimum of capitalism. It does not exist. The question is: Is this accidental or is it causal? Is it impossible to have a competitive, pluralistic, open society without at the same time having some degree of capitalism? Is capitalism the necessary cow dung for the plant of democracy? Do we have to put up with it? There is considerable debate among scholars on the subject. ${ }^{55}$ It is conceivable that we do have to accept the combination of capitalism with democracy. Can we then either a) democratize Islam or redemocratize it, or b) Islamize democracy?

On democratizing Islam, do we make it more a part of the forces at work in our lives that combine accountability to God with accountability to the people? This is one question we have to ask ourselves while making future Islamic history: How do we combine accountability to God with accountability to the people in our governments? Secondly, how do we localize the concept of ummah and make it an electoral constituency rather than a diffuse one billion people in different states of the world? There are one billion Muslims around the world. ${ }^{56}$ Thinking of Muslims as a single constituency is very often unrealistic. Can there be smaller constituencies?

On the question of gender, how do we make Muslim women full participants? Gender could be the interrupted revolution in the original history of Islam. Islam was revealed among a people steeped in female infanticide. Therefore it was sexism at its worst. Allah chose to reveal the religion first of all among people with that defect. Do I have enough or too many daughters? In that case, let's have a pillow ready for the next one. Now that is obviously horrendous in historical terms and yet, within one generation, this society began to have property-owning female citizens. ${ }^{57}$ The society was on its way towards change. The question is, did Allah intend the change to be incremental? You are dealing with raw human material. In the first generation, you may not be able to transform

${ }^{55}$ Two recent works include Dietrich Rueschmeyer et al., Capitalist Development and Democracy (Chicago: University of Chicago Press, 1992); and Gyorgy Lukacs, The Process of Democratization, trans. S. Bernhardt and Nolan Levine (Albany: SUNY Press, 1991).

${ }^{56}$ See Weeks, "The Demography of Islamic Nations," 1988.

${ }^{57}$ See John Thomas Cummings et al., Islam and Development, ed. John Esposito (Syracuse, NY: Syracuse University Press, 1984), pp. 35-6. 
all that you want to transform. Were there seeds of change, for example, in polygyny? When they were told that a man could marry more than one woman provided he treated them equally, was that a seed of changeprovided you treat them equally? You realize that you cannot do so, for it is impossible to treat two human beings equally. You will find one more amusing than another, one more irritating, more restful or more attractive. One may galvanize you more, depress you more, titillate you more. Obviously it is impossible to treat two human beings equally.

My father had more than one wife. One of his widows is still alive and I give her a small portion of whatever little earnings I receive. She was not my biological mother and, although my father died in 1947, she is still part of my family obligation. This shows how long these loyalties last.

On one occasion I saw my father, a chief qāđ̣i of Nairobi, buying a dress as a gift for my second mother, the one who is still alive. I said to him: "I didn't see you buying anything for my mother." My father, alarmed by this observation, said: "Look, your mother is a more traditional woman and she wears particular sorts of things which you don't get in Nairobi. They are better in our home town."

This was perfectly true. The sort of thing my mother wore was more available in Mombasa than Nairobi. On the other hand, I wanted to make trouble, so one day when I was angry with my father, I told my mother about my father's gift. But my mother slapped me and told me to mind my own business.

On the whole, the essential issue to grasp is that although my father was a very learned Muslim jurist and still accepted the permission that a man could have more than one wife, it is possible to take the position that equal treatment was a de facto prohibition in the seed of history, for it is psychologically and physically impossible to fulfill the condition. In the fullness of time, if there were a judicial review in Islam the way there is, for example, in the American system, we may find polygyny declared unlawful, just like slavery. The American system passes judgment on the issue of abortion according to its reading of the American Constitution, although the founding fathers would not have dreamed of discussing such issues in constitution making. And yet here are judges and juries discussing whether or not there are implications on issues of privacy that affect abortion. ${ }^{58}$ Contrast this with the Islamic belief that a man can marry more than one woman, provided he can treat them equally-that is much

${ }^{58}$ See, for example, Dennis J. Horan et al., eds., Abortion and the Constitution: Reversing Roe v. Wade through the Courts (Washington, DC: Georgetown University Press, 1987); and Alida Brill, Nobody's Business: Paradoxes of Privacy (Reading, MA: Addison-Wesley, 1990). 
more explicit than anything in the American Constitution dealing with abortion. Thus it is possible to believe that it was a de facto prohibition.

The gender question should be reexamined, as the gender revolution was intended in Islam but never took off. It was aborted arguably for two reasons: a) mainstream Islam turned royalist from the Ummayids onwards, and the harem developed and became more secluded as a more aristocratic version of Islam developed, and b) the doors of ijtihad closed and the gender revolution was thereby aborted.

As for equalizing democracy, as distinct from democratizing Islam, I mean that we even try to make Islamic values more available to nonMuslim societies. I was quite intrigued in my own country of Kenya, for it has an Islamic party that the government refuses to register. It is a very unusual Islamic party, for it states explicitly that one does not have to be a Muslim to be a member, a supporter, or an office holder. One just has to subscribe to particular Muslim values regarded as fundamental to its program. So it is not a party for a Muslim fraternity, but of Muslim values. A member can belong to some other religion provided that his or her values converge with those of Islam.

For example, in Islam you can minimize drunkenness and drug addiction - two of the main threats to western democracy-when they result in chaos, willful disobedience, and disorder. Due to the strong strain of individualism in western society and the individual's consequent freedom, it is very difficult for the state to infringe on an individual's rights, even if they pose a danger to themselves or to others. ${ }^{59} \mathrm{Can}$ Islam provide avenues of sobriety that could help the West reduce this danger?

In reference to globalizing democracy, Islam was the first religion to ritualize globalism. Praying five times a day, facing a particular direction worldwide wherever the devout Muslim happens to be-this is the ritualization of globalism. The concept of the ummah-the one billion members of the worldwide community of believers-is part of Islamic globalism. Makkah, the aim of pilgrims, is one particular place, still very sacred, where every Muslim is required to attempt to go at least once in his or her lifetime if possible, is part of the globalization. Will this help in the globalization of democracy?

Does Islam have a lot to teach about equality and fighting racism? It is not enough to go capitalist or liberal. There must also be levels of egalitarianism, including racial equality, that Islam started with the first integrated mosque with Sayyidnā Bilāl. Christianity, on the other hand, has had major problems with racism. For instance Jimmy Carter, when

${ }^{59} \mathrm{~A}$ French conservative philosopher sees ominous consequences for western democracies due to the inherent challenges posed by individualist freedom. See Jean-François Revel, How Democracies Perish, trans. William Byron (Garden City: Doubleday, 1984). 
he was President, confessed that his church still kept African-Americans out. It was still an all-white church during Carter's presidency! The Dutch Reformed Church was one of the architects of the apartheid system in the Republic of South Africa. So there are areas of Islamic egalitarianism that the West should be invited to scrutinize, not in order to convert westerners to the Islamic faith but so that they may learn from Islamic values.

\section{Conclusion}

The future may be "post-Western"; it may be "anti-Western." It cannot be "non-Western."

-Peter F. Drunker. ${ }^{60}$

Should, and can, Muslims respond to this challenge? Much of the discussion of the "end of history" focuses on the strengths of the West and therefore assumes the weaknesses of the rest of the world. But if Islam in the twentieth century has not always been the most fertile ground for democracy, it has also been less fertile for some of the greatest evils of this century: Nazism, fascism, communism, and genocide. These have emerged in societies that were Christian or Buddhist or Confucian. Muslims are often criticized for not producing the best, but they are not congratulated for having standards of human behavior that avert the worst. There are no Muslim equivalents of Nazi concentration camps, American racial lynching, apartheid under the Dutch Reformed Church, Japanese racism before or during the Second World War, or genocide under Stalin and Pol Pot. What is it in Islam that insists on minimum standards of humanity and humanness?

If the triumph of liberal democracy required the collapse of communism, let us also remember a point we raised earlier: the collapse of communism required the resistance of Islam. Communism triumphed autonomously in previously Christian countries, such as Russia and Czechoslovakia, in previously Buddhist countries such as Vietnam and Korea and, to some extent, China, a previously Confucian country. But apart from the dubious case of Albania, communism has never triumphed in a previously Muslim country. We have seen fascism in Christian Germany and Italy and in Buddhist and Shintoist Japan. We have never seen fascism in the Muslim world. We have seen no concentration camps in the ummah.

Fukuyama assumed that the "end of history" arrives when we have discovered the best. He forgot that we also need to understand how to

${ }^{60}$ Peter Drucker, Post-Capitalist Society (New York: Harper Business, 1993), p. 214. 
protect ourselves from the worst. We know that western liberal democracy has enabled us to find openness, governmental accountability, popular participation, and high economic productivity. But we also know that western pluralism has been a breeding ground for racism, fascism, Nazism, exploitation, and purposeful, cynical genocide. If history as a quest for the ultimate political order is to come to an end, it can never be satisfied with the message of the West on how to maximize the best in human nature. History must consult Islam about how to check the worst in human nature. From alcoholism to racism, materialism to Nazism, drug addiction to Leninism-of all the value systems in the world-Islam has been the most resistant to the ultimate destructive forces of the twentieth century and perhaps, for the time being, including the dreaded Acquired Immune Deficiency Syndrome (AIDS). It is worth asking if those societies that are closer to the Shari'ah are also more distant from being HIV positive? If so, we should take a closer look as to why that is so.

The "end of history" has to be a marriage of more than one civilization and more than one standard. Muslims must continue to leave behind that middle phase decline as objects of history. I would hope their role as shapers of history will continue. Muslims should continue to pursue local goals and still change extralocal dimensions. But Muslims' resumption of their role as makers of history is perhaps the most important imperative of them all, hopefully awaiting dramatic expansion in the postLeninist age. We should proceed not only to take charge of our own destiny but help to transform the rest of our species.

For much of this century, we were very often no more than passengers on a ship called the S. S. Earth. We were just passengers, sometimes passengers in chains. In the course of the second half of the twentieth century, we began to be members of the crew-at least some of us. We began to be participants in the movements of that ship and in helping to direct its ultimate destination. The question that now arises is: Are we in a position once again to take charge of the ship, if not in this decade, if not in the next decade, not long after that? Are we in a position to take our turn as the collective captain of the S. S. Earth? 